\title{
IMPACTS OF ACTIVITY BASED TEACHING IN SCIENCE SUBJECTS IN SECONDARY PRIVATE SCHOOLS OF KARACHI IN THE CONTEXT OF JOHN DEWEY'S THEORETICAL PERSPECTIVES
}

\author{
Hafiz Aminullah \\ Research scholar PhD Education, \\ Department of Education Hamdard University Karachi \\ aminperfectparadise@gmail.com \\ Muhammad Akhtar Kang \\ Assistant Professor, Faculty of Social Sciences \& Humanities, \\ Hamdard University, Karachi, Pakistan \\ dr.akhtar@hamdard.edu.pk \\ Ahmad Saeed \\ Professor, Faculty of Social Sciences \& Humanities, \\ Hamdard University, Karachi, Pakistan \\ saeedahmadresearch@gmail.com
}

\begin{abstract}
$A B L$ or Activity base learning is the key point of student-centered classroom environment. classroom's learning environment can be changed only by well-planned activities in which students must be engaged according to the theory of John Dewey's theory of learning by doing. The research was made to enhance the importance of ABL in classroom especially for science subjects in Karachi. Since majority of teachers are still using the same old traditional method so it was very necessary to bring a positive change in their teaching style to bring positive impacts over the learning of students. Science is a vast domain, so the research was limited to the teaching of Chemistry at secondary level of Karachi in Privately managed schools. Beside enhancing teachers' capabilities, the other objectives of the research were to find the impacts of $A B L$ in classroom learning environment and its impacts over the personality of children. It is survey research The researcher selected 15 schools from each district of Karachi by using stratified sampling technique and thus total 90 schools were selected and then one of their principals and one teacher who used to teach chemistry there. It is found that teachers are not properly trained to manage and plan ABL in their classroom, so they avoid using this method in their classroom. School management also doesn't support them. The research presented some recommendations for the improvement of classroom environment.
\end{abstract}

Keywords: Activity based learning, Teaching, Science, Private Secondary Schools.

\section{INTRODUCTION}

Dictionary defines science as "a branch of knowledge or study dealing with a body of facts or truths systematically arranged and learned by experiments showing the operation of general laws." (Merriam-Webster). Science is nothing bus to prove the phenomena by experiments and continuously proved phenomena convert into theory and later law. Now it is an annoying situation that the subject, that needs experiments to prove every phenomenon, is being taught just by traditional teaching methods without practical activities. Natural laws are being taught by reading or explanation without any activity and this is a big hurdle to create interest of students at secondary level.

Karachi is the capital of Sindh and the biggest city of Pakistan. More than 5000 privately administrated schools are working in Karachi region (BSEK). They are run either by individuals or by societies. Science is the key subject and teachers are dictating these laws in the class which can be memorized by students, but they cannot go to the depth of these laws and their understanding will be incomplete. This understanding and learning can be enhanced by using ABL (Activity Base Learning) methods in their classrooms. 
Rapid changes in the world demand that students must have basic knowledge when they come forth to the modern world of science. If students do not have interest in their scientific subjects just because of poor teaching methods than they will never make their progress in scientific subjects and they will be stuck in the way.

ABL method just fulfill the basis need of students of learning by doing as oral explanations cannot justify the laws or rules as practical activity would do. Just by oral demonstration students achieve knowledge but their learning cannot be completed until and unless they would not perform that activity and get the desired results by their own. If teachers start explaining the scientific laws by practical or activity method, a zeal must be aroused in students and thirst of knowledge would definitely increase in them. But for this teacher have to teach with their heart and soul and with properly planned lesson planning.

This research is especially designed to analyze the positive and negative impacts of various teaching methods used by different teachers of Karachi and the compare them with activity base learning method and try to bring the different out. This study will try to prove the importance of activity-based method in learning process of students of scientific subjects.

\section{Statement of the problem}

Old and traditional teaching methods are being used by teachers of science subjects in different secondary schools of Karachi. Students are losing their interest in scientific subjects because of the use of old traditional methods. ABL (activity base learning) would enhance their interest in learning again. The research identifies the impacts of activity-based teaching in science subjects in secondary private schools of Karachi in the context of John Dewey's theoretical perspectives.

\section{Objectives of the study}

The main purpose of the study was to bring betterment in teaching styles of teachers of science (chemistry) subjects and to enhance the importance of activity based according to John Dewey's philosophical theory of learning by doing.

The study especially revolved around:

- To analyze teaching through the activity-based method.

- To make teachers realize the importance of activity-based methods for teaching.

- To analyze the level of satisfaction after students were taught through the activitybased method.

\section{Research questions}

- To improve the quality of classroom learning.

- Why is there difference in impacts of ABL method and old traditional methods?

- What can be the difference if ABL methods are used by trained and untrained teachers?

- Is the curriculum student centered and fulfilling the needs of learners?

- Are the students fed up with traditional methods and want to change in classroom learning methods?

- What are the hazards and problems faced by teachers while using ABL method in their classrooms?

- How can management of schools affect the learning atmosphere of classroom?

- What are the impacts of ABL in learning of students?

- How can examination system be improved if practical system will be implemented properly?

\section{Significance of the study}

Teaching and especially teaching of science is no doubt an art. This art would be at its peak if teachers are properly trained, and they can use activity-based teaching methods in their classrooms. This study would help the teachers to emphasize the importance of activity-based methods during their teaching. It would help them to reduce the load of curriculum and to help the students an active participant in classroom learning.

\section{REVIEW OF LITERATURE}

A review of literature verifies the need for this study. Activity based instruction is the form of learning where the learner is actively engaged in a task. The focus is on making the abstract concrete and on learning by doing. It can be teacher-driven - with direction from an instructor - or learnerdriven with the learner having freedom to explore 
There are advantages and disadvantages of this method. ABL methods are enjoyed by those who love to learn by doing. Indeed, it cannot be claimed that all learners would be active learners, but this method at least can increase the ratio of learning. ABL methods are more suitable for active learners, but slow learners can also get benefits from this method. This method can be entertaining and exciting if designed and implemented by teachers properly. It makes it easier to understand the so called difficult scientific rules. ABL methods give freedom to individuals for independent learning and let them explore the knowledge by doing with a proper plan by teachers.

It is not possible that there would be no negative side of a specific method. Hence this method has some disadvantages too. Activity is a part of learning, and it must be balanced with proper management of time and clear goals. If teachers do not take proper interest students would not be able to get anything rather than just fun of being involved in an activity. For example, using paints to make a chart with the goal of learning about graphs and it can be converted to just a common drawing exercise pr practice for fun if teachers would not guide them properly and design the activity go get their desired goals. Commonly it happens in young kids where they cannot realize about the goal of their activity and role of teachers must be shown there properly to guide them to their learning outcomes. Time management would be another important issue in this learning method. Indeed, it needs time and if teacher is not able to manage it, it would go to worst. It is a delicate art of learning without proper planning it would be harmful rather than to bring some good achievement.

Anyhow if it is planned properly comprehension of students would be dynamic and can be tested through practical exercise or activities. Teachers have to be careful to be limited to basic and simple ideas as advance ideas cannot be explained in schools by practical activities. School administration must have a positive role in it, and they should provide basic facilities to teachers to plan their ABL based lessons. (Ramesh, 2011)

\section{Activity Based Learning and Motivation}

Learning is the basic aim of teaching. The main aim of education is to make people learn about different things and empower them with true and right knowledge. Education leads individual towards learning new skills, employment and positivity for the whole society. To fulfill this task the most important person is no one but teacher. They (teachers) must be trained and have competent knowledge about their subjects, and they must be a true facilitator to awake creative thinking and creative skills among students. Creative thinking and creative methods enhance thirst for knowledge in students and they get clearer concepts, and their creative skills develop with the passage of time. As teacher is the facilitator for the students so until and unless he/he is not active effective learning cannot be possible. It's totally depending upon the ability of teachers to create interest in students so that they can make their learning process positive (Ericksen, 1978). He further says that without an able teacher interest cannot develop in the classroom atmosphere. For students' learning effective methods of teaching are necessary. Changing world needs changed methods of teaching and new technology and new methods must be used in class to get better results (Anwer, 2019).

ABL is simply a learning process which is designed to engage the students through any productive activities (Panko, 2007). In this method of learning or teaching all students are engaged to participate in classroom learning process. It is totally against traditional teaching methods as it involves all students to participate in any role and thus, they collaborate with each other, and an environment creates where students take full interest and their learning outcomes become well. They become active learners rather than passive and a healthy and positive atmosphere created in the classroom. Such methods make students so strong that their concepts become clearer and concrete, and their performance becomes higher level. They become able to resolve their issues and their social skills also become better (Churchill, 2003).

How ABL can be beneficial? ABL creates foundation of learning and provoke students to think critically to present themselves but to make it beneficial, it is necessary to engage the students in whole process and it must be student centered. Teachers must have complete knowledge about the activity, and they must be able to manage the timetable of activity otherwise outcomes will be destructive, and no benefits will be gained. There must be interactive activities to make students understand about different concept and their conceptual learning will make them stronger (Anwer, 2019).

Proper communication and activities performed in classroom managed by teachers bring best results in terms of learning. Such repeated activities bring confidence in the students and allowing 
people to ask and to reply makes them sharp and open minded. By natural activities they can learn so much which they cannot learn by simple traditional methods (Prince, 2004).

According to the research of Chafe (1998) individual learning can be improved by collective learning. In ABL method students have to collaborate with each other and often they belong to different cultural backgrounds so a social interaction involves in this type of learning which enhances not only learning of students but also polish their social skills and they can learn to work in groups, and it automatically brings good impact over their results and achievements.

Motivation of students to perform activities is very important for classroom outcomes. Teachers play the vital role in this method as teachers are the main motivational character and he or she would capture all the interest and attention of children in class if the activity is properly planned otherwise no one would take any interest in such activities. Teachers must have knowledge about new technologies, and they would be capable to implement them within their time period and with proper management. Active's teachers can mobilize students and ABL becomes successful. Learning cannot be completed without true motivation. Without motivation good plans can also fail and learning outcomes will not be as per desired. Learning will not be as such great if teachers fail to motivate the students at true level (Spitizer, 1996).

In fact motivation is necessary for all levels of education from preprimary to the highest. Teachers should not forget the importance of motivation in order to making learning meaningful. In $\mathrm{ABL}$ and group work it becomes more important as there involved multi-talented and multicultural students and to entertain all in one activity is really a hard work. Teachers have to realize that different educators have different cultural backgrounds, and their motivation levels are different also and that's why they would always respond at different level. Some might be active, and others are of passive nature. So, to entertain all such motivational explanation is needed where all students feel it is for them (Pintrich, 2003).

ABL method creates interest in students to learn by doing something and such sessions make students to participate in activities with zeal and they start to share their ideas which is start of learning and sign of being motivated.

In this regard it must not be forgotten that teachers are still using old and traditional methods of teaching which really do not support students' critical thinking skills and they have to learn what teacher would teach. They (students) cannot use their own skills\& thought and their previous knowledge also would not be used in the classroom during lesson (Toe \& Wong, 2000).

While when teachers us ABL method the first impact goes on their motivation. ABL does not support any single method but it includes various techniques and methods so students can be facilitated according to their skills and abilities. It guides them towards self-learning and performance so they become good learners and their problem-solving skills would develop with time period. With such activities they learn how to remove hurdles from their learning outcomes and how to make learning more effective and how to improve their own skills. Here teachers can make interesting by adding open dialogue in the end as they should understand the needs of lesson and they can control the whole discussion and make it fruitful (Boud \& Feletti, 1991).

For science subject especially and all subjects generally it is necessary that facilitators must have knowledge about the importance of ABL and they would be ready to implement it in the classroom. Developing countries like Pakistan are facing the problems of clearing basic concepts to the students and ABL is the best way to clear basic concepts of students and for this training of teachers is necessary. After being trained they would be able to implement ABL method in their classrooms effectively (Anwer, 2019).

\section{Why should "activity-based learning method"?}

Students are not bound of memorizing in this method. They are supposed to provide material with proper guidance and strict supervision and let them do their own thinking and start interaction. Teachers only need to facilitate them, and their directions and instructions must be clear and understandable. Teachers guide them all the possible process and what they (student) are supposed to analyze and how they would compare their results with each other to reach on a conclusion. By repeating such methods students' skills develop and they start getting experiences and their concept start to develop and become clear.

\section{Kinds of activities}

There are three main categories of activities or ABL. 
Exploratory in this, students gather knowledge, learn about concepts and explore their skills to make concepts clear.

Constructive

Expressional

Experience starts in this step and students start to learn by their experiments. . After getting enough experience they become able to express their knowledge in the form of presentations

Advantages of ABL

$\mathrm{ABL}$ can be used for any subject and at any level of education. It enhances learning and students can understand what there are supposed to be taught. Social skills, ethic and self-esteem are promoted during this. It guides students to create ideas, get knowledge in doing by hands and use

\section{Disadvantages of ABL}

Students of low ability feel shy to participate and thus they can lose their interest and they become dominant in the classroom. If teachers are not properly planned then it can be proved boring because of its length. Sharp students can push back other students.

\section{REASERCH METHODOLOGY}

\section{Population of the Study}

All secondary schools of Karachi are the population of the study. There are about 5000 secondary schools (privately managed) in all districts of Karachi (BISEK).

\section{Sampling}

By using stratified random sampling, the researcher selected 90 schools from 6 different districts of Karachi; 15 schools from each district.

\section{Design of the Study}

The participants of the study were divided into two groups. The researcher got the responses from principals and teachers. There was total 90 selected schools and a principal and a teacher were selected as sampling so there were 90 principals and 90 teachers to respond.

\section{Research Instruments}

It was a survey research and a questionnaire was formed for both principals and teachers. There were 31 items in the questionnaire. Their replies and percentage of the replies provided the data to make this research easier.

\section{Data Analysis}

First of all, the items' reliability were checked through SPSS and as their value was 0.728 they were supposed to be valid and reliable. Each item was analyzed through simple charts and percentage and the researcher reached on conclusion after getting their responses. Their responses and conclusion were described via charts and paragraphs.

Table No. 1 Case Processing Summary

\begin{tabular}{|l|l|r|r|}
\hline \multicolumn{2}{|l|}{} & N & \multicolumn{2}{|c|}{$\%$} \\
\hline Cases & Valid $^{2}$ & 30 & 78.9 \\
\cline { 2 - 5 } & Excluded $^{\mathrm{a}}$ & 8 & 21.1 \\
\cline { 2 - 5 } & Total & 38 & 100.0 \\
\hline
\end{tabular}

a. Listwise deletion based on all variables in the procedure.

Table No.2 Reliability Statistics

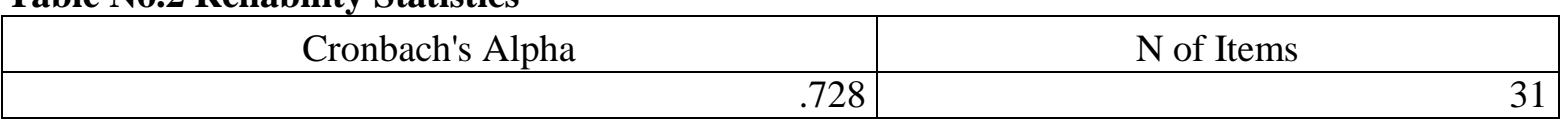

Sample of Data Analysis

1) Science subjects should be taught by different learning activities such as ABL method.

\begin{tabular}{|c|c|c|c|c|c|}
\hline Respondents & SDA & DA & UD & A & SA \\
\hline Teachers & 05 & 10 & 00 & 50 & 25 \\
\hline Percentage & $5.55 \%$ & $11.1 \%$ & $0 \%$ & $55.55 \%$ & $27.75 \%$ \\
\hline Students & 05 & 07 & 03 & 40 & 35 \\
\hline Percentage & $5.55 \%$ & $7.77 \%$ & $3.33 \%$ & $44.44 \%$ & $38.88 \%$ \\
\hline Total & 10 & 17 & 03 & 90 & 60 \\
\hline Percentage & $5.55 \%$ & $9.44 \%$ & $1.66 \%$ & $50 \%$ & $33.33 \%$ \\
\hline
\end{tabular}




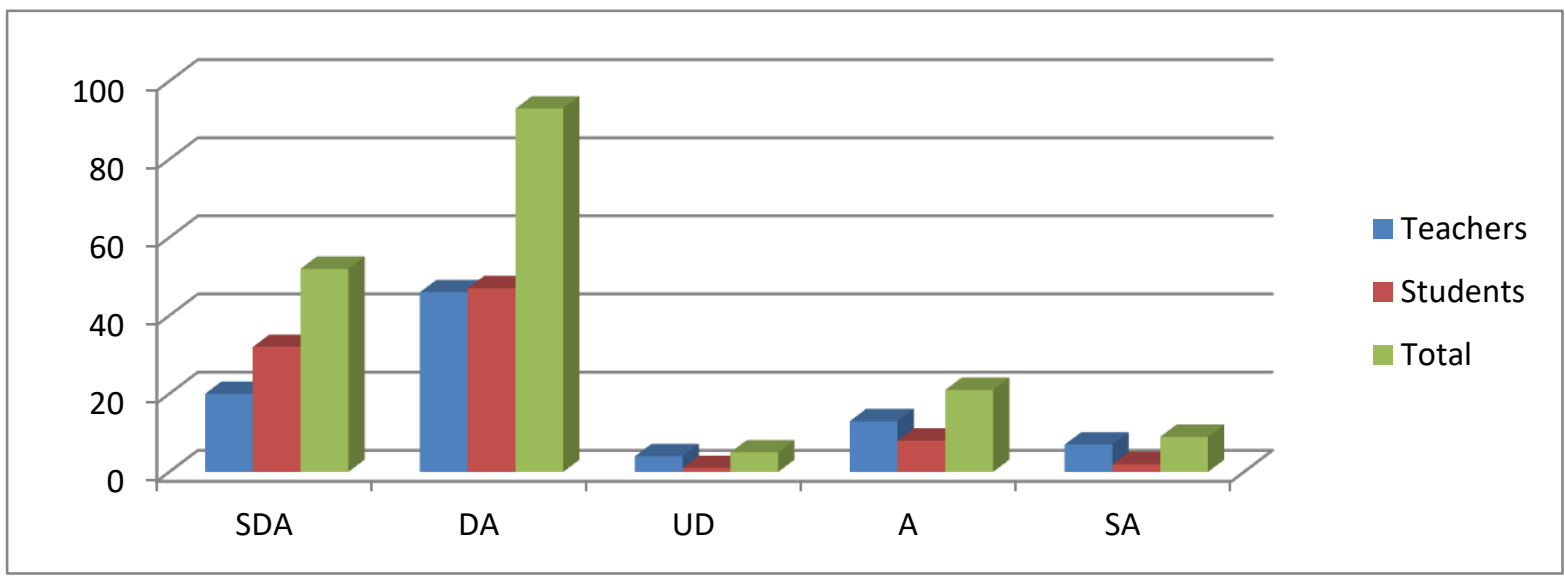

conclusion: $5.55 \%$ teachers were strongly disagreed, $11.11 \%$ were disagreed, $0 \%$ were undecided, $55.55 \%$ were agreed and $27.75 \%$ were strongly agreed While $5.55 \%$ students were strongly disagreed, 9.44\% students were disagreed, $3.33 \%$ students were undecided,50\% students were agreed and $38.88 \%$ of students were strongly agreed. Thus total $5.55 \%$ of respondents were strongly disagreed, $9.44 \%$ were disagreed, $1.66 \%$ were undecided, $50 \%$ were agreed and $33.33 \%$ were strongly agreed. Such a high percentage of respondents made the researcher believe that science subjects should be taught by ABL method.

\section{Sample Of Data Analysis}

2) Trained teachers can utilize ABL methods effectively in classroom.

\begin{tabular}{|c|c|c|c|c|c|}
\hline Respondents & SDA & DA & UD & A & SA \\
\hline Teachers & 00 & 10 & 00 & 60 & 20 \\
\hline Percentage & $0 \%$ & $11.1 \%$ & $0 \%$ & $66.66 . \%$ & $22.22 \%$ \\
\hline Students & 02 & 15 & 00 & 43 & 30 \\
\hline Percentage & $2.22 \%$ & 16.66 & $0 \%$ & $47.77 \%$ & $33.33 \%$ \\
\hline Total & 02 & 25 & 0 & 103 & 50 \\
\hline Percentage & $1.11 \%$ & $13.88 \%$ & $0 \%$ & $57.22 \%$ & $27.77 \%$ \\
\hline
\end{tabular}

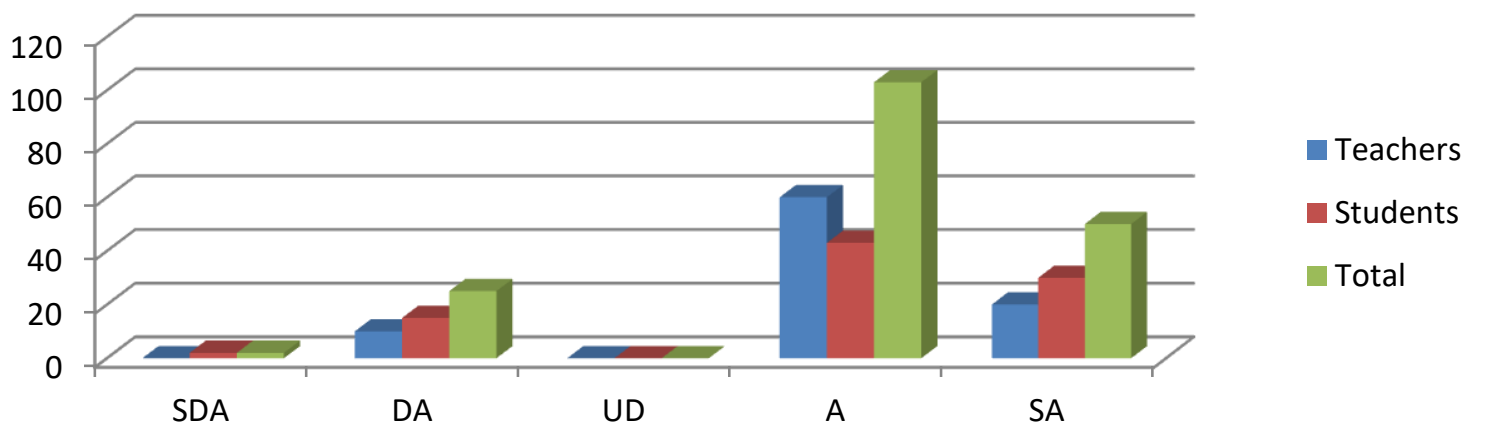

Conclusion: $0 \%$ teachers were strongly disagreed, $11.11 \%$ were disagreed, $0 \%$ were undecided, $66.66 \%$ were agreed and $22.22 \%$ were strongly agreed While $2.22 \%$ students were strongly disagreed, $16.66 \%$ students were disagreed, $0 \%$ students were undecided, $47.77 \%$ students were agreed and $33.33 \%$ of students were strongly agreed. Thus total $1.11 \%$ of respondents were strongly disagreed, $13.88 \%$ were disagreed, $0 \%$ were undecided, $57.22 \%$ were agreed and $27.77 \%$ were strongly agreed. Such a high percentage of respondents made the researcher believe that trained teacher can utilize ABL method effectively in classroom. 
Sample of Data Analysis

3) Old traditional methods are better than ABL method..

\begin{tabular}{|c|c|c|c|c|c|}
\hline Respondents & SDA & DA & UD & A & SA \\
\hline Teachers & 20 & 46 & 4 & 13 & 07 \\
\hline Percentage & $22.22 \%$ & $51.11 \%$ & $4.44 \%$ & $14.44 . \%$ & $7.77 \%$ \\
\hline Students & 32 & 47 & 01 & 08 & 02 \\
\hline Percentage & $35.55 \%$ & $52.22 \%$ & $1.11 \%$ & $8.88 \%$ & $2.22 \%$ \\
\hline Total & 52 & 93 & 5 & 21 & 9 \\
\hline Percentage & $28.88 \%$ & $51.66 \%$ & $2.77 \%$ & $11.66 \%$ & $5 \%$ \\
\hline
\end{tabular}

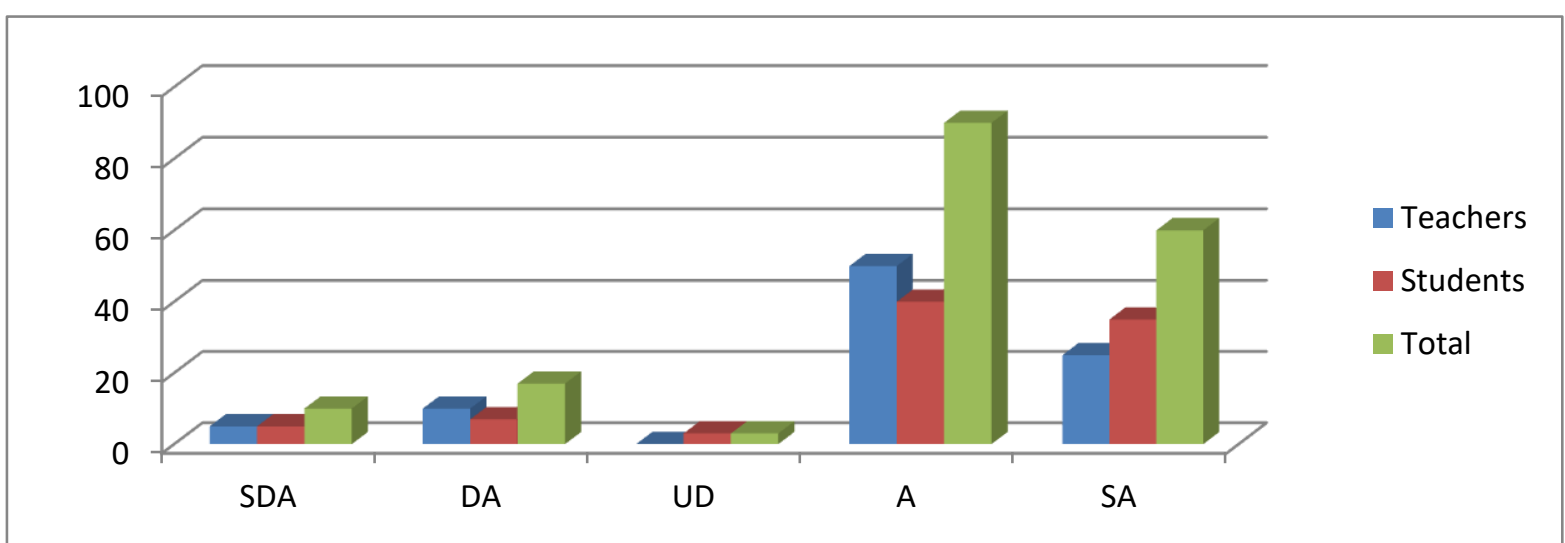

Conclusion: $22.22 \%$ teachers were strongly disagreed, $51.11 .11 \%$ were disagreed, $4.44 \%$ were undecided, $14.44 \%$ were agreed and $7.772 \%$ were strongly agreed While $35.55 \%$ students were strongly disagreed, $52.22 \%$ students were disagreed, $1.11 \%$ students were undecided, $8.88 \%$ students were agreed and $2.22 \%$ of students were strongly agreed. Thus total $28.88 \%$ of respondents were strongly disagreed $51.66 \%$ were disagreed, $2.77 \%$ were undecided, $11.66 \%$ were agreed and $5 \%$ were strongly agreed. Such a high percentage of respondents were disagreed with the statement and researcher concluded that old traditional methods are not better than ABL

In this way all 30 items were analyzed, and the researcher concluded the following findings.

\section{FINDINGS OF THE STUDY}

- ABL method is important for learning, and it creates interest in class.

- It needs proper time management so only trained teachers should adopt this method.

- ABL methods of teaching provoke hidden abilities of students.

$\circ$ Teachers are reluctant to adopt ABL method in their classroom because of many reasons such as time issues and management.

$\circ$ Refresh training courses are necessary for teachers to enhance and share their skills and experiences.

$\circ$ Untrained teachers face problems in time management when they try to use ABL methods in their classroom environment.

- Traditional descriptive teaching methods cannot create interest in science subjects.

- Students learn skills and social interaction during such activities.

- Administration is not quite helpful for the students and teachers in this regard.

- Practical system is being ignored at secondary level.

- Practical marks are assigned to the school management and they award them to students without true performance so students are not ready to perform practical.

- Science subjects are being assessed without practical.

- Schools are missing proper teaching aids and even labs.

- Schools are not ready to spend on teaching aids for ABL.

- Principals think it is time consuming method and syllabus would not be completed.

$\circ$ Management thinks that practical can be taught so there is no need of doing them. 


\section{CONCLUSION}

In modern time of education, teachers cannot enhance skills of students until and unless they will not plan for them to involve in positive educational activities. ABS is such an art that involves students in useful activities and bring their potentials out of them. Because of many reasons ABL methods have been ignored that should not be. ABL method is helpful for students.

\section{RECOMMENDATIONS}

$>$ Practical should be given due importance.

$>$ Smaller scientific labs must be formed for students.

$>$ Science subjects should not be taught with descriptive method only. Practical or learning by doing must be added.

$>$ Science subject should not be assessed without real practical work.

$>$ Small assignment should be given to students to engage them in practical activities.

$>$ Teachers must have knowledge about new methods and techniques.

$>$ Refresh course for teachers should be planned.

$>$ ABL methods must include in syllabus of schools and management should provide teaching aids to teachers.

Dovernment should provide aid to schools to start ABL method.

$>$ Management must be supportive to teachers.

\section{REFERENCES}

Alexander, J. G., Baldwin, M. S., \& McDaniel, G. (2000, July). Authentic Assessment of ProblemBased Learning [Electronic Version]. Journal of Alabama Academy of Science, 71 (3), 89.

Anderson, O. R. (1992). Some interrelationships between constructivist models of learning and current neurobiological theory, with implications for science education. Journal of Research in Science Teaching, 29(10), 1037-1058.

Anwar, F. (2019). The effect of activity-based teaching techniques on student motivation and academic achievement. Journal of Education and Educational Development, 6(1), 154-170

Aronson, E. Jigsaw in 10 Easy Steps. Retrieved February 28, 2003 from http://www.jigsaw.org

Barnes, L. B, Christensen, C. R., \& Hansen, A. J. (1994). Teaching and the Case Method: Text, Cases and Readings (3rd Ed). Boston Massachusetts: Harvard Business Schools Press.

Boud, D., \& Feletti, G., Eds. (1991). The challenge of problem-based learning. New York: St. Martin's Press.

Chafe, A. (1998). Cooperative Learning and the Second Language Classroom. Retrieved from http://www.stemnet.nf.ca/ achafe/cooplang.html

Churchill, D. (2003). Effective design principles for activity-based learning: The crucial role of 'learning objects' in science and engineering education. Paper Presented at the Ngee Ann Polytechnic, 2.

Erickson, S. C. (1978). The Lecture. Memo to the Faculty, 60. Ann Arbor: Center for Research on Teaching and Learning, University of Michigan

Hake, R. R. (1998). Interactive-engagement versus traditional methods: A six-thousand-student survey of mechanics test data for introductory physics courses. American Journal of Physics, 66(1), 64-74.

Mazur, E. Peer Instruction: Getting Students to Think in Class. Retrieved March 21, 2003, from Harvard University http://www.psrc-nline.org/classrooms/papers/pdf/mazur.pdf.

Panko, M., Kenley, R., Davies, K., Piggot-Irvine, E., Allen, B., Hede, J., \& Harfield, T. (2005). Learning styles of those in the building and construction sector. Report for Building Research, New Zealand.

Pintrich, P. R. (2003). A motivational science perspective on the role of student motivation in learning and teaching contexts. Journal of Educational Psychology, 95(4), 667.

Prince, M. (2004). Does active learning work? A review of the research. Journal of Engineering Education, 93(3), 223-231. Retrieved from http://ctlt.jhsph.edu/ resources/views/content/files/150/Does_Active_Learning_Work.pdf

Ramesh, M. (2011). http://activitybasededucation.blogspot.com/2011/07/abl-merits-and-demerits.html 
Spitzer, D. R. (1996). Motivation: The neglected factor in instructional design. Educational Technology, 36(3), 45-49.

Teo, R., \& Wong, A. (2000). Does problem based learning create a better student: A reflection. 2nd Asia Pacific Conference on Problem-Based Learning: Education Across Disciplines (pp. 4-7).

\section{Webliography}

http://en.wikipedia.org/wiki/Educational_research)

http://researchrundowns.wordpress.com/intro/whatisedresearch/Creswell, 2002)

http://www.collinsdictionary.com/dictionary/english/activity-method)

http://www.gmu.edu/resources/facstaff/part-time/strategy.html)

http://eprogressiveportfolio.blogspot.com/2012/06/activity-based-teaching-method.html

https://www.merriam-webster.com/dictionary/science. 